would be later discovered that these 'antidepressants' or 'mood stabilisers' are also effective antipsychotic agents. For these reasons, $71.7 \%$ of psychopharmacology conference attendees that participated in a survey agreed that the current terminology was inadequate or confusing. ${ }^{5}$

\section{Implications}

Clinicians and researchers must be aware of the power of names and how they use these words. Clinicians should particularly be aware of the power of these labels to their patients. We must be aware that using these words creates expectations and consequences that go beyond the communication of one of the properties of a specific chemical. To this end, the initiative of the Taskforce on Nomenclature, established in a collaborative effort of four major colleges of neuropsychopharmacology (American College of Neuropsychopharmacology (ACNP), European College of Neuropsychopharmacology (ECNP), Asian College of Neuropsychopharmacology and International College of Neuropsychopharmacology (CINP)) to create a new multi-axial pharmacologically driven nomenclature, is beginning to address and resolve the problem. ${ }^{5}$
Rif S. El-Mallakh, MD, Sabine Doenninghaus, PhD, Mood Disorders Research Program, Department of Psychiatry and Behavioral Sciences, University of Louisville school of Medicine, Louisville, Kentucky, USA

Correspondence: Rif S. El-Mallakh, Mood Disorders Research Program, Department of Psychiatry and Behavioral Sciences, University of Louisville School of Medicine, MedCenter One, 501 E Broadway, Suite 340, Louisville, Kentucky 40202, USA. Email: rselma01@|ouisville.edu

First received 26 Aug 2014, final revision 29 Apr 2015, accepted 13 May 2015

\section{References}

1 Dönninghaus, S. Die Vagheit der Sprache: Begriffsgeschichte und Funktionsbeschreibung anhand der tschechischen Wissenschaftssprache [The Vagueness of Language: History of a Concept and Description of its Functions based on Czech Academic Discourse]. Harrassowitz Verlag: 2005.

2 Huang CC. Persistent tardive dyskinesia associated with amoxapine therapy - two case reports. Hillside J Clin Psychiatry 1986; 8: 209-13.

3 Singh GP. Amoxapine-induced tardive dyskinesia. Indian J Psychiatry 2009; 51: 327.

4 Apiquian R, Fresan A, Ulloa R, Ede la Fuente-Sandoval C, Herrera-Estrella M, Vazquez A, et al. Amoxapine as an atypical antipsychotic: a comparative study vs risperidone. Neuropsychopharmacology 2005; 30: 2236-44.

5 Zohar J, Nutt DJ, Kupfer DJ, Moller H-J, Yamawaki S, Spedding M, et al. A proposal for an updated neuropsychopharmacological nomenclature. Eur Neuropsychopharmacology 2014; 24: 1005-14.

'Hat on, hat off!' A memorable clinical encounter

\title{
Reza Kiani
}

On my first day to review patients at a day centre for people with intellectual disabilities, the parents of one of the patients proudly introduced their son to me: 'This is Gary, who has defied medical opinion for 50 years. He is a fighter, doc!' Gary was a non-verbal wheelchair user with a profound intellectual disability and treatment-resistant epilepsy. But he was also a happy soul and a joy to be with

Soon after he was born his parents were warned that he would not survive to see his first birthday but he proved everyone wrong; his parents were preparing to celebrate his birthday soon by taking him on holiday.

I reviewed Gary's seizure diary, meticulously kept by his mother. Frustratingly, it was full of multiple types of epileptic attacks ranging from partial seizures and myoclonic jerks to tonic-clonic attacks. These occurred relentlessly on a daily basis in spite of him being on various anti-epileptics. He had already been seen and discharged from a tertiary epilepsy centre and the local epilepsy clinic, as 'nothing else could be done to [treat] his complex epilepsy'.

On one of the pages of the diary, I noted a strange entry: 'hat on, hat off!' This was written in the antecedent column, where other triggers such as respiratory infections were also recorded. Surely, I asked myself, I had misread his mother's handwriting? But no, this was correct. Apparently, years ago when Gary was under the care of a senior colleague (who had retired well before I joined as a senior registrar), his parents were told to pull the flat cap that he used to wear down over his eyes to help prevent clusters of partial seizures getting worse or evolving into severe tonic-clonic attacks. To my amazement, his mother said that this did the trick and still does sometimes, even when nothing else can help. She was adamant that this simple measure had helped reduce the use of rescue medications and emergency admissions for prolonged seizures. Her explanation, which seemed plausible, was that Gary was more relaxed and less anxious, as the visual stimuli including bright lights, known triggers in some types of epilepsy, were eliminated by pulling the hat over his eyes for a few minutes until he settled down again.

The mother talked about my colleague who had given them that advice: 'Not all the professionals were pessimistic. She used to look at the books and reassure us that if a medication did not work, there would be something else that could be tried. She even came to our house to do blood tests early in the morning ( . . . ) if needed. Something that nobody else would do, she was a wonderful doctor, like a family member, she was!'

On my way back to hospital that day, I was full of admiration for my retired colleague. I also thought of how simple acts of kindness, practical optimism and empathetic gestures by a professional who was there for the family were remembered after such a long time. 